\title{
UK academics see research income rise
}

London. Research in British universities appears to be booming, according to the publication last week of statistics showing that the research income per full-time academic scientist has trebled in cash terms over the past ten years.

But in a statement accompanying the announcement, the Committee of Vice Chancellors and Principals (CVCP), said the rise in research income from $£ 12,000$ (US $\$ 19,200$ ) per academic to $£ 36,000$ coincided with a fall in public investment.

Furthermore, according to the 1995 edition of the CVCP's University Management Statistics and Performance Indicators in the $U K$, expenditure on university libraries, if taken as an indicator of infrastructure investment, fell by 22 per cent in real terms in the decade between 1984 and 1994.

The CVCP survey does not indicate which sources provided most research income. But a separate report published last month by the Universities Statistical Record shows that funding from the European Union and from UK charities had risen the most, by 27 and 18 per cent respectively, over the past year; in contrast, spending by UK industry rose by only 7 per cent, and by the government by 5 per cent.

The Association of University Teachers, the academics' labour union, has given a mixed reaction to the statistics. Monica Hicks, a spokeswoman for the union, acknowledges that diverse sources of income free universities from the "whims of government". But she describes the fall in public investment as "a national disgrace". Investment in universities, says Hicks, "is the responsibility of government", not least to protect 'blue skies' research.

Out of the 37 broad subject bands covered by this year's CVCP survey, biochemistry has replaced clinical medicine as the field attracting the most money per head. Research income per full-time biochemistry academic was found to be just under $£ 96,000$, compared to $£ 74,000$ in $1991-92$.

The University of Leicester has overtaken Dundee as the most productive venue for biochemistry research. Leicester's income per full-time academic jumped from $£ 123,000$ in $1991-92$ to $£ 237,000$ in $1993-94$. The University of Oxford came second with $£ 214,000$, and Imperial College, London, third at $£ 162,000$.

Materials science, mineral engineering and physics were the other strong performers, attracting $£ 94,000, £ 82,000$ and $£ 76,000$ respectively. In the first category, Queen Mary and Westfield College, University of
London, and the University of Birmingham were neck-and-neck, each attracting over $£ 191,000$ per academic.

Heriot-Watt University $(£ 280,000)$ continues to dominate mineral engineering, while University College London $(£ 151,000)$ overtook the University of Cambridge $(£ 149,000)$ to head the physics table.

The section on graduate unemployment shows that while there are fewer long and short-term jobless science graduates, unemployment continues to rise among zoology, botany, chemical engineering, mineral technology and genetics graduates.

Unemployment of recent genetics graduates rose from 16.8 per cent in 1992-93 to 17.9 per cent in 1993-94; while the number of out-of-work biotechnologists, having fallen from 21.6 per cent to 10.3 per cent in 1992-93, rose to 25.8 per cent.

The CVCP statistics were compiled from information received from government research councils, government ministries, industry, overseas sources and charities. The figures apply only to the United Kingdom's 56 'old' universities. Next year's statistics will include information from all of the former polytechnics that were accorded university status under the 1992 Further and Higher Education Act.

\section{Europe approves energy funding - but blocks projects}

Paris. For many scientists, getting a research programme approved can be easy compared with obtaining the requested funds. The European Union (EU) has now created the opposite problem. It has approved the spending by the European Commission of ECU30 million (US\$39 million) on a programme on renewable energy, while at the same time refusing to approve the programme itself.

The dispute has arisen over the future of part of THERMIE, a research programme that ran from 1990 to 1994 . One part is assured annual funding of ECU100 million, as it is part of the ECU967-million 'nonnuclear energy' section of the fourth Framework programme, which lasts from 1994 to 1998. It was considered eligible because it funds 'demonstration projects' of technologies considered too young and risky for industry to finance.

But the commission has ruled that the remaining part of THERMIE, which deals with testing demonstration projects under different economic and geographical conditions, cannot legally be included in Framework because it is concerned with economic rather than technological risks.

To meet this problem, the commission has proposed a separate ECU30-million-ayear programme, confusingly called THERMIE II. Both Germany and the United
Kingdom, however, oppose this proposal, arguing that they agreed to the overall envelope for renewable energy research when they signed up for the Framework budget and are not prepared to pay a penny more.

Officials in the UK Department of Trade and Industry add that both countries also

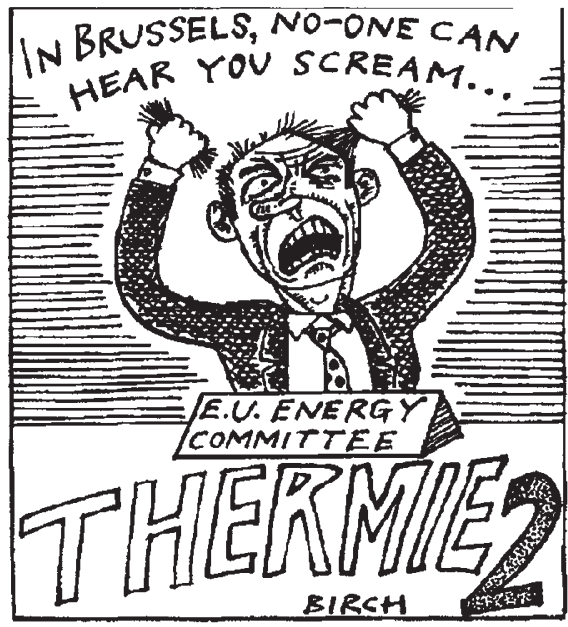

oppose the proposal as being too near-market, and claim it could set a precedent of using EU research funds as industrial subsidies, thus distorting the market.

The issue took on an air of absurdity when the dispute reached the council of ministers - the body through which member states are represented directly in Brussels - earlier this year. The 13 member states in favour of the proposal were able to push through its budget on a majority vote; but Germany and the United Kingdom were able to block adoption of the programme, as this requires unanimity.

Last month, the energy committee of the European Parliament condemned the council for "endangering" research centres across Europe. As the parliament has no powers in this area to contest the council decision formally, it issued a resolution calling on council to "recognize the need to adopt the programme".

The result of the stalemate is that ECU30 million is now sitting in a bank, earmarked for renewable energy research; but not a penny can be spent. In an attempt to resolve the issue, Christos Papoutsis, the energy commissioner, has suggested an informal tripartite meeting between the council, the commission and parliament.

The issue will probably be discussed at a meeting of the council of energy ministers on 1 June. By then, a solution may be even more elusive; France, which initially opposed the proposal but had a change of heart during its current six-month term as president of the EU, may have reverted to its initial position.
Declan Butler 